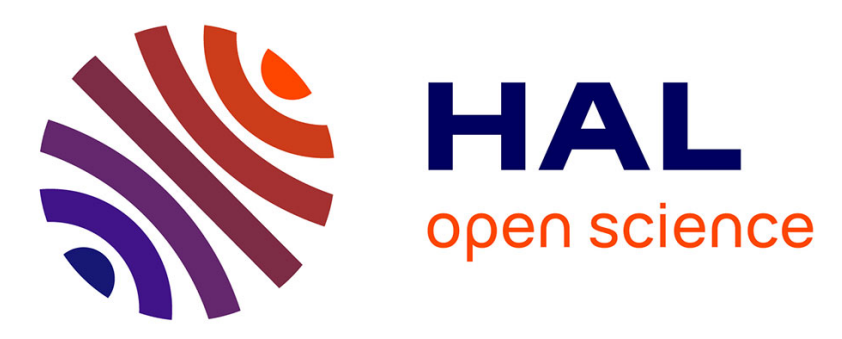

\title{
What do children aged four to seven know about the digestive system and the respiratory system of the human being and of other animals?
}

\author{
Susana Garcia-Barros, Cristina Martínez-Losada, María Garrido
}

\section{To cite this version:}

Susana Garcia-Barros, Cristina Martínez-Losada, María Garrido. What do children aged four to seven know about the digestive system and the respiratory system of the human being and of other animals?. International Journal of Science Education, 2011, pp.1. 10.1080/09500693.2010.541528 . hal-00680173

\section{HAL Id: hal-00680173 \\ https://hal.science/hal-00680173}

Submitted on 18 Mar 2012

HAL is a multi-disciplinary open access archive for the deposit and dissemination of scientific research documents, whether they are published or not. The documents may come from teaching and research institutions in France or abroad, or from public or private research centers.
L'archive ouverte pluridisciplinaire HAL, est destinée au dépôt et à la diffusion de documents scientifiques de niveau recherche, publiés ou non, émanant des établissements d'enseignement et de recherche français ou étrangers, des laboratoires publics ou privés. 


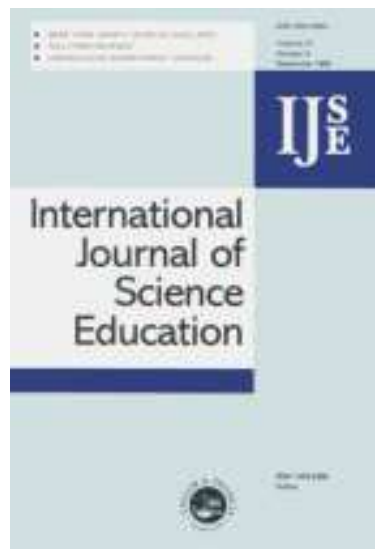

What do children aged four to seven know about the digestive system and the respiratory system of the human being and of other animals?

\begin{tabular}{|r|l|}
\hline Journal: & International Journal of Science Education \\
\hline Manuscript ID: & TSED-2009-0364.R3 \\
\hline Manuscript Type: & Research Paper \\
\hline Keywords : & biology education, early years, conceptual development \\
\hline Keywords (user): & \\
\hline
\end{tabular}

\section{SCHOLARONE ${ }^{\text {m }}$}

Manuscripts 


\section{What do children aged four to seven know about the digestive system and the respiratory system of the human being and of other animals?}

\section{Introduction}

The study of the life functions of the human being and of other closely related animals is particularly interesting as early as the first grade of schooling. Nutrition is a process which fulfils an indispensable life-maintaining function and studying it provides useful knowledge which contributes to our understanding of how living beings function in general and human beings in particular. Moreover, the subject of nutrition may be connected with developing healthy eating habits. (Banet, 2001; Cakici, 2005). However, learning about it is complicated (Caravita \& Hallden, 1994), because it requires integrating the roles of digestion, respiration, blood circulation, etc., which take place in a set of different organs/systems, into the global nutrition process. More specifically, children's concepts develop from a simple idea - living beings need to take certain materials from their environment (food, water and air) in order to live - to other more complex ones. Children should thus gradually begin to recognise that these materials reach some specific internal organs, that they are transformed by those organs and that they are then distributed to the different parts of the body through the blood so as to obtain the matter and energy that are essential for the maintenance of life (Pujol, 2003). Furthermore, children should come to understand that waste substances are produced inside the body and that they need to be eliminated by means of specific organs.

The Spanish Official Curriculum sets great store by nutrition in general, but it goes more deeply into human nutrition in particular, starting as early as 6-7 years of age. In Early Childhood Education (before 6 years of age), stress is placed on the 
external characteristics and the needs of the human being and other living beings around them (feeding, respiration, etc.). In the Primary School curriculum, comprising children aged six to twelve, the human being's feeding and respiratory functions are included in the first stage as well as those of animals in general (ages 6-8); the organs which permit such functions to be performed are included in the second stage (ages 8-10) and the systems involved in nutrition and their interrelation are treated in the third stage (ages 10-12). Greater detail is given to these last aspects regarding the human being than where other organisms are concerned.

The importance attributed to breathing and feeding by the Curriculum as early as the very first Years of education accounts for the need to know how children of these ages interpret the inside of their bodies. It is particularly valuable for teachers to have this knowledge before introducing these themes, since it helps them promote the development of their pupils' ideas.

There are different interpretations as to how young children acquire their ideas about biology. Some authors, such as Carey (1985), give them a mainly psychological origin, which refers to extrapolation from humans to other biological systems. Other authors (Mintzes, 1984; Hatano \& Inagaki, 1997) consider that children gradually build up their biological knowledge during the first years, either through personal experiences or based on knowledge conveyed in the family context. These experiences account for the fact that even young children are aware of the existence of certain organs (Cuthbert, 2000; Reiss \& Tunnicliffe, 2001a) and that they, in their turn, relate them to other perceivable processes (stomach-eating, lungs-breathing...) (Cubero, 1998).

The objective of some research conducted in this area has been to determine what pupils' knowledge looks like and what possible learning obstacles there are in connection with the functions of the organs/systems in the human body which take part 
in nutrition (Table 1). Most research projects have chiefly focused on studying the ideas of adolescents, while research aimed at young children is rather scarcer especially in Spain. This chart shows us that most of these studies are aimed at anatomical and/or functional aspects of the digestive system and, to a lesser extent, at the respiratory system or the systems of the human body as a whole. On the other hand, these research projects normally focus on human nutrition while those that deal with other animals, such as Reiss' study (2001b), which uses other species of vertebrates, are less frequent. Furthermore, the goal of these studies is to get to know the characteristics of the ideas that pupils of different ages have about this particular field. However, the longitudinal ones, which involve monitoring the individual ideas of subjects over a period of time, are less abundant.

The research projects included in Table 1 also show that the youngest children have naive ideas with regard to the organs which make up the digestive and respiratory systems. Children associate the stomach with respiration. Moreover, they relate liquid elimination directly to organs belonging to the digestive system. Furthermore, the transformation of food is not recognised.

\section{TABLE 1}

Characterising the pupils' knowledge has been done by means of different methodologies (surveys, closed and open questions...). Drawings, however, seemed to be an ideal methodology, especially to work with young children (Guichard, 1995; Renie \& Jarvis, 1995), because it allows us to detect their mental models (Buckley et al., 1997) and to compare the conceptions of subjects from different countries with different languages (Reiss et al., 2002). Regardless of the data-collecting instruments used for learning about pupils' ideas, these projects established levels, models and 
categories of different degrees of complexity. For instance, Reiss \& Tunnicliffe (2001a), proposed seven levels for depicting the inside of the human body. The easiest levels were characterised by the inability to recognise the organs or by depicting them in an unconnected way, and the most complex ones were characterised by the ability to recognise various interconnected systems. Teixeira (2000), suggested three models of perception of food intake and its destination. The most primitive model was characterised by food remaining in the abdominal area and the most advanced one was characterised by the ability to recognise the manner in which food is distributed inside the body. On the other hand, Carvalho et al. (2004) established three different categories with regard to three questions: how is the digestive tract anatomy depicted?; how are the changes taking place from the mouth to the intestine interpreted?; and how is the distribution of food in the body understood? Specifically, the simplest categories involving the digestive tract anatomy were associated with the absence of a digestive structure or the ability to identify a "sac" which may or may not be connected to the mouth. The most complex categories were characterised by the ability to identify organs that are more or less correctly associated to a continuous digestive tube.

Finally, it is worth pointing out that research has detected not only epistemological obstacles, associated with personal perceptions and experiences, but also didactic ones, promoted by teaching, which make accurate learning more difficult. Thus, deficient drawings, sketches and diagrams have been found in Portuguese Primary Education textbooks. They turn out to be too confusing and they do not make interpreting the interrelations between the different systems which take part in human nutrition easy (Carvalho et al., 2007). Similar deficiencies, as well as others related to physiological aspects of nutrition, have been found in Spanish texts (García Barros \& Martínez Losada, 2005). 
What has been said thus far, has lead us to the conclusion that our research ought to focus on aspects which previous research projects have paid less attention to. To be precise, our study is aimed at young children and it focuses on how children perceive the organs/systems related not only to digestion, but to respiration as well. The study is not only aimed at the human being, but it includes other animals too. On the other hand, this research project does not only deal with the ideas of children belonging to different age groups, but it likewise monitors how the personal ideas of these children develop over time.

The first objective of this paper is to learn how children aged four to seven interpret where that which enters the body is meant to go, concerning both human beings and other animals, i.e.: Where does drink and food go?; Where does the air they breathe go? What specific organs are identified in each case? A second objective is aimed at finding an answer to the following question: How do the pupils' individual ideas develop in connection with the aforementioned aspects over a three-year period?

\section{Methodology}

In all, 342 pupils from four different age groups (76 aged four, 74 aged five, 101 aged six and 91 aged seven), who are in the second and third year of Early Childhood Education and in Primary School Year 1 and Year 2 respectively, participated in this study. All of these predominantly middle class children belong to the same school in A Coruña (north-western Spain). There is hardly any teaching staff rotation at all and the teachers are highly experienced. More specifically, the staff teaching in the Years where this study was undertaken had more than 15 years experience at that particular Educational Stage. In these years/forms, pupils work on different aspects related to the functions carried out by the human being and other 
animals (they feed, they breathe and have children/baby animals...). They do not, however, study the different organs and systems involved in those processes (digestion, respiration...). The Spanish Education System deals with these aspects from Primary School Year 3 and on (8-9 years of age).

The study of children's ideas about the digestive and the respiratory system or the organs related thereto was performed both concerning the human being and other vertebrate animals. Two different criteria were followed when choosing the animals: a) they should belong to the everyday sphere of life and be known to young children; b) they should be varied as far as their morphology (they have skin, feathers...) and their natural environment (sea, land, etc.) are concerned. Based on this, and after conducting a before-study of what the youngest children know about different animals, the following ones were selected: dog, duck and fish.

Our research has focused on anatomical aspects related to the passage of different substances (food, drink and air) inside the body. We have ignored the physiological aspects, because they are beyond the scope of this paper. Besides, they are too complex and abstract for children of the age groups chosen for this study. This decision is based on the results that were obtained through a pilot study carried out with some children. Their answers to questions such as - What purpose does food serve? Why do we breathe? What happens to the food that we take in? - turned out to be very elementary and they nearly only referred to things like: "we breathe to live"; "we eat to be strong”; "food enters our bodies, goes to our bellies... and that's how we become strong”, etc. These first results essentially coincide with those found in other research projects (please refer to Table 1), which show that the youngest children, and even those not quite so young, do not know that food is transformed once it enters our bodies. 
With the aim of learning what young children know about the digestive system and the respiratory system and what organs are associated to each one of them, the following questions were posed to them in connection with the human being and the animals chosen for this study: a) "Where does the food that you eat and the liquid that you drink go?" and b) "Where does the air that you breathe in go?". The children had to express their ideas by means of drawings, individually. They were given silhouettes of the four specimens for that purpose in the following order: first, the human being, then the dog, duck and finally the fish. After that, the children were to identify what their drawings depicted.

The manner of asking the questions and the way the drawings should be done, were adapted to the different ages of the participants. Thus, the children aged four to five, who still do not know how to write, were asked the questions individually. Each subject did the drawings required of them in the silhouettes and after that they identified what they had drawn, verbally. The place chosen for these activities was a classroom which the children were familiar with and which did not contain too many decorative elements distracting the children. On the contrary, the children aged six to seven, who knew how to read and write, were asked the questions collectively in the group that they belonged to, in their own classrooms. Each child did the drawings required of them in the silhouettes and subsequently identified the organs in writing. These data were collected during Term 2 (January-February) of the academic year.

The children's drawings were classified into different categories, which were progressively more complex, taking into account not only where substances come in and go out, but the organs included as well. A before-analysis of a representative number of drawings carried out for the different specimens was undertaken for this very purpose. 
As regards the path which food and drink follow inside the body, none of the children included the kidneys as excretion organ and they depict the solids (faeces) and liquids (urine) as leaving the body directly from the digestive system. Therefore, the following categories were established with regard to the digestive system: $A_{D}$ (only the entrance to the stomach); $\mathrm{B}_{\mathrm{D}}$ (including the exits too); $\mathrm{C}_{\mathrm{D}}$ (including the intestines as well). $A_{D}$ and $B_{D}$ were subdivided in accordance with the type of entrance they have (single or double) (see Figure 1). The term stomach has been used, although the children themselves may employ others such as "tummy" to identify things in their drawings.

As for the respiratory system, the categories established were: $A_{R}$ (ways in/out, without any internal organs); $B_{R}$ (including an organ, but not the lungs); $C_{R}$ (including the lungs as well as other organs) and $D_{R}$ (including the lungs only). In categories $B_{R}$ and $\mathrm{C}_{\mathrm{R}}$, in their turn, subcategories were established depending on which organs had been drawn (see Figure 2). This time, the before-analysis showed that some children drew a different organ (gills) in the case of the fish, wherefore it became necessary to establish a specific category, namely $E_{R}$, for that example (Figures 3).

The drawings were analysed, independently, by two judges. Those cases where an agreement could not be reached were discussed, though their disagreements did not exceed $5 \%$ of the drawings they analysed.

The longitudinal study, i.e. the study aimed at finding out how the personal ideas of a specific group of children develop over time, was conducted with 32 subjects during three consecutive years (from the age of five to the age of seven). These 32 children belonged to the initial group attending Early Childhood Education during the first year of the study and then remaining in the school during the following two years, i.e. also taking the first two years of Primary Education there. These children were 
asked the same questions, and in the very same way, as the rest of the participants, orally at the age of five and then in writing during the following years.

\section{Results}

\section{Children's ideas about the digestive system}

The children made the same digestive-system related depiction concerning all the examples of animals (including human) and they always managed to identify an organ. In all of the cases, the children drew a "bag" or "sack" which they called "stomach" or "tummy" Only a small number of children were able to identify the intestine as well.

Most of the drawings made by the differently-aged children corresponded to categories $\mathrm{B}_{\mathrm{D} 1}$ or $\mathrm{B}_{\mathrm{D} 2}$ (Table 2). Category $\mathrm{B}_{\mathrm{D} 1}$ (two ways in to the stomach and two exits from that same organ) was the most frequent one in the groups of four- and five-yearolds. In these groups, however, other more primitive categories were detected as well, namely $A_{D 1}$ o $A_{D 2}$ (with no exits at all). Category $B_{D 2}$ (only one entrance) was the most frequently found one in the groups of six- and seven-year-olds. In these last groups, a small percentage of drawings corresponded to the most advanced category, namely $C_{D}$, which includes the intestine. Figure 1 shows some representative drawings from each one of the categories.

\section{TABLE 2}

FIGURE 1

\section{How do children's ideas regarding the digestive system develop?}

The study of the drawings of the digestive system, made by a subgroup of students that involved repeated assessments (32 children from the age of five to the age 
of seven), shows that 23 of them evolved as they become older. Table 3 describes the characteristics of that evolution. Most of them modified their type of answer only once during the three-year period. Only three of them made different depictions every year. Virtually all of the children's last drawings corresponded to the $\mathrm{B}_{\mathrm{D} 2}$ (16 children) (One entrance from the outside to the stomach and a double exit to the outside from this organ) or $\mathrm{C}_{\mathrm{D}}$ (7 children) categories (One entrance from the outside to the stomach; there is a connection to the intestine; there is a double exit from this last organ). Ten of the sixteen children who reached the $\mathrm{B}_{\mathrm{D} 2}$-category initially made $\mathrm{B}_{\mathrm{D} 1}$-type drawings (their evolution consisted in being able to recognise that there is only one entrance) and six children made more primitive initial drawings $\left(A_{D 1} / A_{D 2}\right)$ (their evolution consisted in being able to recognise that there are two exits). Five of the seven children who reached the most advanced category, namely the $\mathrm{C}_{\mathrm{D}}$-one, initially made $\mathrm{B}_{\mathrm{D} 1}$-type drawings (their evolution consisted in including the intestine as well as being able to recognise that there is but one entrance to the stomach) and two children initially made $\mathrm{B}_{\mathrm{D} 2}$-type drawings (their evolution consisted in including the intestine).

The nine children who did not experience any sort of evolution at all always made the same drawings, namely the type corresponding to categories $\mathrm{B}_{\mathrm{D} 2}$ (five children) and $\mathrm{B}_{\mathrm{D} 1}$ (four children).

\section{TABLE 3}

\section{Children's ideas about the respiratory system}

As regards the respiratory system, the vast majority of the differently-aged children (296 in all) made the same depiction in the human being as in the other animals, although they did not always identify the internal organs, especially not the youngest ones (Table 4). Besides, the organs identified by them were diverse: stomach, heart and lungs. Only 46 children, which belonged to the groups of five- six- and seven- 
year-olds, drew different organs in the fish compared to the other three specimens (human being, dog and duck).

\section{TABLE 4}

The respiratory system was depicted in a more varied manner then the digestive system. Table 5 shows the categories which the children's drawings fall into. In the group of children who made the same depiction for all the specimens (Group 1), the $A_{R^{-}}$ type categories, which are characterised by a single entrance/exit for air and by not including the internal organs, were mainly detected in the drawings of children aged four and five. However, at the age of five more than $35 \%$ of the children made drawings corresponding to category $\mathrm{B}_{\mathrm{R} 1}$ (ways in/out connected to the stomach). On the other hand, the $C_{R^{-}}$or $D_{R^{-}}$type categories, which are characterised by including the lungs, were more frequent in the drawings of children aged six and seven. The most accurate category, namely $D_{R}$ (Only the lungs are recognised), was seen in the group of sevenyear-olds, in particular. The $\mathrm{C}_{\mathrm{R}}$-type categories, which include other organs in addition to the lungs, were found in both groups. $\mathrm{C}_{\mathrm{R} 3}$ (ways in/out are connected to the heart and that same organ is connected to the lungs) and $\mathrm{C}_{\mathrm{R} 2}$ (this one also connects the lungs to the stomach) included the largest number of student responses. The most primitive ones, such as $B_{R 1}$, which amounted to about $20 \%$, were likewise seen in these groups of older children. Figure 2 shows some representative examples of drawings from each category.

Those children's drawings of the respiratory system of the fish which separated this specimen from the rest corresponded to one sole category, namely $E_{R}$ (ways in/out connected to the gills) (Figure 3). Like with the other three animals, those same children made drawings that corresponded to $\mathrm{C}_{\mathrm{R}}$-or $\mathrm{D}_{\mathrm{R}}$-type categories (see group II in Table 5). The $C_{R}$-category was only found in the groups with the eldest children, $C_{R 3}$ being the most frequent one. 


\section{TABLE 5}

\section{FIGURE 2}

\section{FIGURE 3}

\section{How do children's ideas develop with regard to the respiratory system?}

The study of the drawings of the respiratory system, made by the subgroup of 32 children aged five to seven, shows that 20 of them made the same drawings for all the specimens in each one of all the tests carried out all through the three-year period. The other twelve children made a different depiction of the fish at some point of the study. All of them drew gills when they are six and seven years old and but three of them drew gills when they were five. The study also shows that the drawings of 23 children actually changed over time, whereas the drawings the rest of them made (nine children) neither changed nor evolved to more accurate scientific categories (Table 6).

Of those 20 children who did not establish any differences between the four specimens (see Group I in Table 6), 14 evolved during this period, thereby reaching $D_{R}$ or $\mathrm{C}_{\mathrm{R}}$-type categories. Generally speaking, the children modified their sort of answer only once throughout the three years; no more than five made different depictions every year.

Of those children who reached the most advanced category, namely $D_{R}$, which is characterised by the lungs being the only organs, six subjects initially made drawings that corresponded to the most primitive categories $\left(A_{R 1} / A_{R 2}\right)$, where no internal organs at all were recognised. Only two children made previous drawings corresponding to the $\mathrm{B}_{\mathrm{R} 1}$-category. In this case, their evolution consisted in substituting an accurate organ (the lungs) for an inaccurate one (the stomach). Those children who reached categories $\mathrm{C}_{\mathrm{R} 2} / \mathrm{C}_{\mathrm{R} 3}$, which include not only the lungs but other organs as well (stomach and/or heart), initially made either $B_{R 1}-/ B_{R 2}$-type (three children) or $A_{R 1} / A_{R 2}$-type drawings 
(three children). In all of these cases, the evolution consisted in including the lungs and either keeping or including inaccurate organs.

As for those six children who did not further their drawings into more accurate categories, only one of them made the same depiction $\left(B_{R 1}\right)$ during the three years. Three children who initially made $\mathrm{D}_{\mathrm{R}}$-type drawings whose last drawings fell into the $\mathrm{C}_{\mathrm{R} 2}-/ \mathrm{C}_{\mathrm{R} 3}$-type categories. This meant that they had incorporated more organs. The other two children who initially made $B_{R 1}$-type drawings produced $A_{R 2}$-type drawings at the end of the three-year period. This meant that they had eliminated the organ which they had initially depicted (the stomach).

\section{TABLE 6}

The study of those twelve children who indicated a difference between the fish and the other three specimens shows that, at some point during the period which has been studied, nine children evolved as they became older with regard to these three specimens (human being, dog and duck) and they did so by modifying their drawings once (see Group II Table 6). Their evolution was characterised by changes which were similar to the ones seen among the children who established no differences between the fish and the rest of the specimens: five children reached the most advanced type of depiction $-D_{R}-$ starting from either $A_{R 1}$ (three children) or $B_{R 1}$ ( two children) and four children reached type $C$ starting from $B_{R}$. The changes in remaining three children were characterised by going from $D_{R}$ to $C_{R}$.

\section{Discussion}

This study has shown that young children have a conception of the inside of the body, even without having studied this subject formally at school. This knowledge is possibly influenced by their empirical experiences, but also by everyday conversations with different people, the audiovisual media and even by the fact that some broader 
contents, which exceed the ones included in the official curriculum, related to this subject are introduced in their own classrooms. On the other hand, it appears that the ideas which young children have about the inside of the human body are usually the same as the ones they have for other animals which they are familiar with. So it is that children generally make the same drawing, with the same organs, for all of the specimens and only a few of them are able to identify the fish as being different by drawing its gills. This suggests that children at these ages, perhaps, use their own body as a basic model of the functions of living beings until they acquire specific knowledge through formal or non-formal education.

As a result of examining children's ideas about the destination of the food that they take in and the air that they breathe, we found that pupils aged four to seven have a more accurate view of the digestive system than of the respiratory system. In the specific case of the digestive system, all of the children, even the four-year-olds, identified the stomach as the place where both solid and liquid foods go. They always depicted the stomach, which some of them also named tummy, as a sack connected to the mouth by one or two canals. These results are similar to the ones found by other researchers undertaking studies of children of similar ages (Giordan \& Vecchi, 1988; Cubero, 1998; Teixeira, 2000 1148; Carvalho et al., 2004; León-Sánchez et al., 2005). As opposed to what happened in our study, however, children do not always depict the place/places where food enters the body (Carvalho et al., 2004). We likewise detected that all of the older children made somewhat more complex drawings of the digestive system. These drawings were characterised by the fact that they included the places where food exits the body, which were always two in number and that they were always connected to the stomach or the intestine, in case this last organ was identified. This suggests that school children aged six to seven have an idea about the digestive system 
as being a continuous one going from the mouth to the excretion orifices, although students in the study never recognised the kidneys as excretion organs.

The differences between the ideas that children of different ages have which were found in the broader study, which was carried out including all of the participants, is consistent with the analysis that was carried out with a small group of children over a three-year period. During those three years, no great changes took place as regards the children's ideas about the digestive system, because none of the children went from the most primitive conception (where only the entrance/s for food and drink to the stomach is recognised) to the most highly developed one (where one single entry leading to the stomach and from there to the intestine, which in its turn is connected to two exits, is recognised). However, it may be stated that those ideas did improve as the children grew older. One of the improvements that were detected consisted in the ability to recognise that the digestive system has an exit and that that exit is, furthermore, a double one. Even though this idea does not establish a difference between the digestive system and the excretion system, it did involve an improvement which may be particularly influenced by the subject's experiences. For instance, young children know that if they take in food which is spoiled they will later have diarrhoea, or of they drink more than usual they will produce more urine. These experiences logically contribute to children establishing relationships between that which is taken in and that which is eliminated. This could also justify the fact that only a small number of young children in the broader study did not recognise the exits of the digestive system.

Another one of the improvements that were detected was that of substituting a single entrance for the double entrance - one for solids and one for liquids - from the mouth to the stomach. However, it should be remembered that the idea that there are two entrances did persist in the groups containing older subjects. We put this 
persistence down to the fact that children are not empirically experienced enough to counteract the establishment of the following causal relationship: if liquids and solids exit through different canals, it is logical to think that they also enter through different canals.

Finally, including the intestine was an improvement which consisted in adding a new organ without modifying, substantially, the initial model of the digestive system, which was characterised by a series of organs connected to one another from the mouth to the excretion orifices. Including the intestine is not very frequent, neither in the longitudinal study nor in the global study. We believe that those who did include it did so fundamentally owing to the general knowledge which they had acquired by means of conversations, access to sketches, drawings of the inside of the body found in books, exhibitions, museums, etc. and so forth.

As we have said, children aged seven manage to acquire a more complete idea about the anatomy of the digestive system, generally speaking. However, pupils, the oldest ones too, have been found to have difficulty establishing relationships between different organs even after studying the digestive system as such (Reiss \& Tunnicliffe, 2001a). This could be influenced by the teaching method as well as by the classroom material. Specifically, textbook sketches and drawings do not always treat the interconnections between those organs accurately (Carvalho \& Alves, 2004). In our opinion, the teaching process ought to take into consideration the adequate idea about the digestive system which most pupils seem to show ("a continuous tube" where the substances that come in are different to the ones that go out), so as to contribute to the understanding that transformations do indeed take place inside it. This is important, especially because taking such transformations into account is not easy for pupils at all 
(Gellert, 1966; Contento, 1981; Brinkmann \& Boschhuizen, 1989; Cubero, 1998; Teixeira, 2000; Rowlands, 2004).

As has been previously said, the children have a more inaccurate conception of the respiratory system than of the digestive system. So it is that particularly the youngest ones did not identify any of the respiratory system organs, while the eldest ones included the lungs and/or other organs (stomach, heart) outside the system as a part of it. These results coincide with the ones found by other researchers (Brinkmann \& Boschhuizen, 1989; Cuthbert, 2000) and they can possibly be put down to the fact that children do not have such evident empirical experiences here as they do of the digestive system. In any case, the children did not appear to have any problems identifying the number of organs of each type, even though they made this mistake. They knew, even the youngest ones, that the lungs are two organs and that the stomach and the heart are only one. However, the lungs were depicted in such a way that they looked similar to two bags resembling the stomach, while the heart was drawn looking like a heart of "two lovers" or a "Saint Valentine's" one, thereby showing a clear cultural influence.

The fact that the children, above all the youngest ones, did not recognise any of the respiratory system organs could be influenced by their inability to recognise air as matter (Stavy, 1988; Seré, 1989). Thus, children may think that air is capable of spreading inside the body. Moreover, there are no personal empirical facts inducing them to think that air transforms itself inside the body. In fact, there are no noticeable differences between inhaled and exhaled air. Therefore, the need for a specific organ inside the body, as is the case with the digestive system, is not perceived. However, there were a large number of subjects who recognised the stomach as the only breathing-related organ, thus leading us to presume that some children "needed" air just like food and drink - to reach the only cavity in the body they were able to identify 
(tummy/stomach). This conception persisted despite the fact that the children identified the lungs as organs belonging to the respiratory system.

On the other hand, regardless of the number of organs considered to be a part of the respiratory system, the children tended to establish connections between those organs and they always maintained a certain order of appearance. More specifically, the heart was drawn before the lungs, while the stomach was situated after them. There may be a possible explanation for this order. However, simply analysing the children's drawings did not permit us to make any interpretations. In order to do so, it would be necessary to make interviews enabling us to study the children's thought more in depth. As opposed to what happens with regard to the digestive system, the children did not always depict the respiratory system the same way for the human being as for other animals. A small group of subjects, all of them over five years of age, identified the gills as the fish's only respiratory organs and they drew them as some sort of lines looking similar to a shark's gill clefts. Perhaps, this was influenced by their own experience acquired at school, but outside it as well. Initially, this group of children could be considered to have more accurate conceptions than the rest of their school mates, since they also identified the lungs as the respiratory organs of the human being and of other animals too. However, this consideration needs qualifying, because a substantial number of these children included other organs outside the respiratory system in these specimens.

The longitudinal study of the smaller group of children showed that the changes were more varied with regard to this system than the ones detected regarding the digestive system. This was consistent with the greater variability of ideas identified concerning the respiratory system, because there was a greater number of organs to be considered there. In fact, the number of categories established is virtually twice as big as 
those referring to digestive system. Furthermore, this time we found that most of the children did gradually acquire more accurate ideas during the three years of the study.

Focusing now on the characteristics of the changes going towards more accurate conceptions, without taking the particular case of the fish into account, it could be observed that some were more extensive than others. For instance, coming to identify the lungs as the only respiratory organs, when starting from an initial idea where no organs at all were considered, constituted a desirable improvement which did not encounter any sort of "interference" along the way. However, coming to that conviction when starting from the idea that the stomach is a breathing-related organ, appears to be rather more difficult, because it requires substituting a specific organ (the lungs) where only air ends up, for the stomach, which is a polyvalent organ where everything that enters the body ends up. This greater degree of difficulty may possibly explain why various children, during this three-year period, added the lungs to the stomach, though they initially considered it to be the only respiratory organ, rather than substituting one organ for another.

In connection with the regressions, we noticed that it is worth highlighting that most of them were characterised by adding other organs (stomach and/or heart) outside the respiratory system to an accurate initial idea (i.e. that the lungs are the system's only organ). This suggests that children are more prone to relate "new" organs to the respiratory system than to the digestive one, which makes it more difficult to teach them about the former. Yet another regression consisting in the initial belief that the stomach is the place which air reaches, only to be replaced by a vague vision of air inside the body, was detected. Even though this change may be seen as a step backwards, it does constitute an idea which can eventually come to be productive, because it helps to understand the fact that air needs to reach all parts of the body. 
Finally, we ought to point out that when the fish's gills were identified, they were considered to be the sole and exclusive respiratory organ of this species. Those children who did identify them did not include other organs outside them, even though they did so where other animals were concerned. This may be due to the fact that the gills were viewed more as an external organ where air or water circulates and the need for an internal organ (heart, tummy/stomach) was therefore not perceived.

\section{CONCLUSIONS AND TEACHING CONSIDERATIONS}

Ever since they were very young, the children in this study had a view of how to depict the inside of their body and they recognised different digestion and respiratory related organs. The older the children were, the more complex and/or accurate their ideas. These depictions of their own body were the same as those used for other animals which they were familiar with and but a few of them were able to distinguish the fish's respiratory organs.

The children's conceptions of the digestive system were more complete than those of the respiratory system. Regarding the digestive one, they always recognised an organ which is specific to it, but when it came to the respiratory system they did not always identify organs, and "other" organs outside this system were often included. The organs identified in both systems were connected to one another and they communicated with the outside.

Analysing the way these children's ideas evolved showed us that their conceptions regarding the digestive system typically either advanced or remained unchanged. Furthermore, quite an accurate idea of this system was reached by most children (continuous tube with one or two main organs - stomach/intestine - which has two exits leading to the outside). However, where the respiratory system was concerned, the 
evolution was more varied and not always was an accurate idea of this system achieved (the lungs as the only organs specific to the system).

This paper shows that young children are able to reflect how they perceive the inside of the body as well as the inside of other animals that they are familiar with by means of drawings. This methodology is valuable but yet has limitations. Using one which stresses the thought of the subjects more deeply, such as interviewing them, would make it possible to answer different questions raised by this study - for what reason do children associate the heart with breathing and never with digestion?; what is the function of the heart?; what view do children have about fishes' gills compared with the lungs?, etc.

This paper provides information about children's thought which may be useful for those who teach about the inside of the human body and the way it functions. There are positive aspects about children's thought which ought to be taken into account if the pupils ideas are to progress. We are specifically referring to the fact that children in this study did not appear to have any difficulty connecting the organs that they considered to be associated to a certain system to one another. However, this connection did constitute a problem for the older pupils, who knew about other organs in greater detail through schooling. This paper likewise shows that children have a more accurate concept of the digestive system than of the respiratory one. Even though the academic requirements are low in Primary Education and even though the curriculum at this level limits itself to the study of gaseous exchange, it is nonetheless necessary for the teacher to bear in mind the fact that it is very hard for children to admit that air is, in fact, matter. It would therefore be advisable for the teacher to include the type of experiences which make it evident that air is material: to perceive that matter enters our body when we breathe; to observe that air takes up space (an upside-down glass vertically introduced into water is 
not filled, because it contains "matter", i.e. air), and so forth. We believe that understanding that air is actually matter is vital if pupils are later expected to be able to grasp that air reaches some specific organs (lungs, gills...), that these organs are related to a distribution system (the circulatory system) which is in charge of taking one of its components (oxygen) to the different parts of the body... and that, in short, all of these processes, when they are accurately integrated, contribute to the nutrition function, which consists in obtaining the matter and the energy which living beings need.

\section{References}

Banet, E. (2001). Los procesos de nutrición humana. Síntesis, Madrid.

Brinkmann, F. \& Boschhuizen, R. (1989). Preinstructional ideas in biology: a survey in relation with different research methods on concepts of health and energy. Research and developments in teacher education in the Netherlands, 75-90.

Buckley, B., Boulter, C. \& Gilbert, J. (1997). Towards a typology of models for science education. In Exploring models and modelling in science and technology education, ed. Gilbert, J., pp. 90-105. University of Reading, Reading, UK.

Cakici, Y. (2005). Exploring Turkish upper primary level pupils' understanding of digestion. International Journal of Science Education 27, 79-100.

Caravita, S. \& Hallden, O. (1994). Re-framing the problem of conceptual change. Learning and Instruction 4, 89-111.

Carey, S. (1985). Conceptual change in childhood. The MIT Press, Cambrige MA.

Carvalho, G., Silva, R. \& Clément, P. (2007). Historical Analysis of Portuguese Primary School Textbooks (1920-2005) on the Topic of Digestion. International Journal of Science Education 29, 173-193. 
Carvalho, G. \& Alves, G. (2004). Values and science contents in Portuguese ptimary School textbooks on the topic human reproduction and sex., ed. 506015 EpFB-cC-C-. University of Minho, Portugal.

Carvalho, G., Silva, R., Lima, N. \& Coquet, E. (2004). Portuguese primary School children'sconceptions about digestion: identification of learning obstacles. International Journal of Science Education 26, 1111-1130.

Contento, I. (1981). Children's thinking about food and eating: A piagetian-based Study. Journal of Nutrition Education 13, 86-90.

Cubero, R. (1998). La construcción del conocimiento del proceso digestivo. Un estudio longitudinal. In Investigación e innovación en la Enseñanza de las Ciencias, ed. Banet, E. \& De Pro, A., pp. 102-110. DM, Murcia.

Cuthbert, A. J. (2000). Do children have a holistic view of their internal body maps? School Science Review 82 (299), 25-32.

García Barros, S. \& Martínez Losada, C. (2005). La nutrición en textos escolares del último ciclo de primaria y primero de secundaria. Enseñanza de las Ciencias VII Congreso Internacional sobre Investigación en la Didáctica de las Ciencias. $\mathrm{N}^{\mathrm{o}}$ extra.

Gellert, E. (1966). Children's conceptions of the content and functions of the human body. Genetis Psychology Monographs 65, 293-405.

Giordan, A. \& Vecchi, G. (1988). Los orígenes del saber. Diada, Sevilla.

Guichard, J. (1995). Designing tools to develop the conception lf learners. International Journal of Science Education 17, 243-253.

Hatano, G. \& Inagaki, K. (1997). Qualitative changes in intuitive biology. European Journal of Psichology of Education 21, 11-130.

Jaakkola, R. O. \& Slaughter, V. (2002). Children's body knowledge: Understanding 'life' as a biological goal. British Journal of Developmental Psychology 20, 325-342. 
León-Sánchez, R., Barrera García, K. \& Palafox, G. (2005). Las ideas de los niños acerca del proceso digestivo. Enseñanza de las ciencias 7. Numero extra VII Congreso Internacional de Didáctica de la Ciencias Experimentales.

Mintzes, J. J. (1984). Naive theories in biology: children's concepts of the human body. School Science and Mathematics 84, 548-555.

Nagy, M. H. (1953). Children's birth theories. Journal of Genetic Psychology 83, 217-226.

Pujol, R. M. (2003). Didáctica de las ciencias en la Educación Primaria. Síntesis educación, Madrid.

Reiss, M. J. \& Tunnicliffe, S. D. (2001a). Student's understandings of human organs and organ systems. Research in Science Education 31, 383-399.

Reiss, M. J. \& Tunnicliffe, S. D. (2001b). Students'understandings about organs and organ systems in different animals. In III Conference of European Researchers in Didactic of Biology, ed. García Rodeja I., Harms, U., Jiménez Aleixandre, M. P., pp. 113-125. Universidad de Santiago de Compostela, Santiago de Compostela.

Reiss, M. J., Tunnicliffe, S. D., Andersen, A. M., Bartoszeck, A., Carvalho, G., Chen, S., Jarman, R., Jónsson, S., Manokore, V., Marchenko, N., Mulemwa, J., Novikova, T., Otuka, J., Teppa, S. \& Van Rooy, W. (2002). An international study of young peoples' drawings of what is inside themselves. Journal of Biological Education 36, 58-64.

Renie, L. J. \& Jarvis, T. (1995). Children's choice of drawings to communicate their ideas about technology. Research in Science Education 25, 239-252.

Rowlands, M. (2004). What do children think happens to the food they eat? Journal of Biological Education 38, 167-171.

Seré, M. (1989). El estado gaseoso. In Ideas científicas en la infancia y la adolescencia, ed. Driver, R., Guesne, E. \& Tiberghien, A. MEC/Morata, Madrid. 
Stavy, R. (1988). Children's conception of gas. International Journal of Science Education 10, 553-560.

Teixeira, F. M. (2000). What happens to the food we eat? Children's conceptions of the structure and function of the digestive system. International Journal of Science Education 22 - 5 - 507, 507-520. 
Table 1 A review of the research projects undertaken regarding the ideas which children have about human and animal nutrition related aspects.

\begin{tabular}{|c|c|c|}
\hline Authors & $\begin{array}{c}\text { Ages and } \\
\text { Instrument }\end{array}$ & Subject/Conclusion \\
\hline (Nagy, 1953) & $\begin{array}{l}5-11 \\
\text { Multiple- } \\
\text { choice test and } \\
\text { drawings }\end{array}$ & $\begin{array}{l}\text { Digestive system/Gaseous Exchange system of the human body } \\
\text { - The children recognise the most specific organs related to } \\
\text { digestion and respiration (stomach and lungs). } \\
\text { - They associate each organ to an existential need (eating, } \\
\text { breathing) }\end{array}$ \\
\hline (Gellert, 1966) & $\begin{array}{l}\text { 4-16 } \\
\text { Interview and } \\
\text { drawings }\end{array}$ & $\begin{array}{l}\text { Organs and systems of the human body } \\
\text { Up to } 10 \text { years of age: } \\
\text { - The children relate the stomach to respiration, which they limit to } \\
\text { the gaseous exchange. } \\
\text { - They are not aware that food is transformed (food is stored in the } \\
\text { stomach and is subsequently expelled). }\end{array}$ \\
\hline $\begin{array}{l}\text { (Contento, } \\
1981)\end{array}$ & $\begin{array}{c}5-11 \\
\text { Interview }\end{array}$ & $\begin{array}{l}\text { Digestive system of the human body } \\
\text { - The children are not aware that food is transformed } \\
\text { - They consider the stomach to be a "warehouse" for the food. }\end{array}$ \\
\hline $\begin{array}{l}\text { (Giordan \& } \\
\text { Vecchi, 1988) }\end{array}$ & $\begin{array}{l}\text { 4-adults } \\
\text { Questionnaire } \\
\text { with drawings }\end{array}$ & $\begin{array}{l}\text { Digestive system of the human body } \\
\text { Some anatomical inaccuracies are detected at all ages: } \\
\text { - Differentiated transit for solids and liquids. } \\
\text { - Inadequate connections between the organs of the digestive } \\
\text { apparatus. }\end{array}$ \\
\hline $\begin{array}{l}\text { (Brinkmann \& } \\
\text { Boschhuizen, } \\
\text { 1989) }\end{array}$ & $\begin{array}{l}\text { 4-11 } \\
\text { Questionnaire } \\
\text { with drawings }\end{array}$ & $\begin{array}{l}\text { Digestive system/Gaseous Exchange system of the human body } \\
\text { - The very youngest ones make simplistic anatomical depictions } \\
\text { of the digestive system. Furthermore, they relate the stomach to } \\
\text { respiration. } \\
\text { - The eldest ones recognise food transformation. }\end{array}$ \\
\hline (Cubero, 1998) & $\begin{array}{l}8-10 \\
\text { Interview and } \\
\text { drawings }\end{array}$ & $\begin{array}{l}\text { Digestive system of the human body } \\
\text { Five different increasingly complex levels of understanding of the } \\
\text { digestive process are identified: } \\
\text { - The most primitive one identifies a "bag" where food is stored. } \\
\text { - At the most highly evolved levels, the transit of food through } \\
\text { different organs is identified. The most advanced of all } \\
\text { recognises food transformation and the distribution of } \\
\text { substances to the entire organism. }\end{array}$ \\
\hline $\begin{array}{l}\text { (Cuthbert, } \\
\text { 2000) }\end{array}$ & $\begin{array}{c}7-11 \\
\text { Drawings }\end{array}$ & $\begin{array}{l}\text { Various systems of the human body } \\
\text { Some anatomical inaccuracies are detected: } \\
\text { - The children do not include any connections or do not connect } \\
\text { the stomach, the lungs and the heart adequately. }\end{array}$ \\
\hline (Teixeira, 2000) & $\begin{array}{l}4,6,8,10 \\
\text { Interview and } \\
\text { drawings }\end{array}$ & $\begin{array}{l}\text { Digestive system of the human body } \\
\text { Three increasingly complex models are identified: } \\
\text { - The simplest models identify the "tummy" as the place where } \\
\text { food goes and it either stays there or is expelled to the outside. } \\
\text { - The more complex models recognise that one part of the food is } \\
\text { eliminated and that another part is distributed throughout the } \\
\text { body by means of the blood. Few children take the } \\
\text { transformation of food into account. }\end{array}$ \\
\hline $\begin{array}{l}\text { (Reiss \& } \\
\text { Tunnicliffe, } \\
\text { 2001a; 2001b) }\end{array}$ & $\begin{array}{c}5-20 \\
\text { Drawings }\end{array}$ & $\begin{array}{l}\text { Organs and systems of the human body and of various animals } \\
\text { They identify seven increasingly complex levels of internal } \\
\text { structure: } \\
\text { - In the most primitive levels, the systems are not identified, they } \\
\text { only identify some organs. The most well-known ones } \\
\text { correspond to the digestive system and the gaseous exchange } \\
\text { system. } \\
\text { - In the most highly evolved levels, systems of interconnected } \\
\text { organs are identified. } \\
\text { In general, they show greater knowledge of the human body than } \\
\text { about that of other animals. }\end{array}$ \\
\hline
\end{tabular}




\begin{tabular}{|c|c|c|}
\hline $\begin{array}{l}\text { (Reiss et al., } \\
\text { 2002) }\end{array}$ & $\begin{array}{c}7 \text { and } 15 \text { years } \\
\text { Drawings }\end{array}$ & $\begin{array}{l}\text { Organs and systems of the human body } \\
\text { They identify the previously defined seven increasingly complex } \\
\text { levels in the drawings made by subjects from eleven different } \\
\text { countries. } \\
\text { - In general, similar average levels of knowledge are identified in } \\
\text { children of different ages from different countries. }\end{array}$ \\
\hline $\begin{array}{l}\text { (Jaakkola \& } \\
\text { Slaughter, } \\
\text { 2002) }\end{array}$ & $\begin{array}{c}4-10 \\
\text { Interview and } \\
\text { drawings }\end{array}$ & $\begin{array}{l}\text { Digestive system/Gaseous Exchange system of the human body } \\
\text { - The children only identify the most representative organs } \\
\text { (stomach, lungs). } \\
\text { - From the age of eight, they relate certain organs to specific } \\
\text { functions (stomach-digestion, heart-blood...). }\end{array}$ \\
\hline $\begin{array}{l}\text { (Carvalho et al., } \\
\text { 2004) }\end{array}$ & $\begin{array}{c}5-6,8-9 \\
\text { Questionnaire } \\
\text { with drawings }\end{array}$ & $\begin{array}{l}\text { Digestive system of the human body } \\
\text { Four types of anatomical depictions are identified: } \\
\text { - The simplest ones only recognise the stomach/tummy, with no } \\
\text { connection to the outside or to the mouth. } \\
\text { - The most complex ones recognise other organs. } \\
\text { Limited knowledge of the digestive process and of the distribution } \\
\text { of substances to different parts of the body is detected. }\end{array}$ \\
\hline $\begin{array}{l}\text { (Rowlands, } \\
\text { 2004) }\end{array}$ & $\begin{array}{c}10 \\
\text { Interview and } \\
\text { drawings }\end{array}$ & $\begin{array}{l}\text { Digestive system of the human body } \\
\text { - The children recognise that food is distributed throughout the } \\
\text { body to obtain energy, though they limit digestion to being a } \\
\text { mechanical process. }\end{array}$ \\
\hline$(\mathrm{Cal}$ & $\begin{array}{c}10-11 \\
\text { Interview and } \\
\text { questionnaire }\end{array}$ & $\begin{array}{l}\text { Digestive system of the human body } \\
\text { The children recognise that one part if the food is eliminated, but } \\
\text { another part is distributed throughout the body by means of the } \\
\text { blood. } \\
\text { - They limit digestion to a "melting and dissolving" process. }\end{array}$ \\
\hline $\begin{array}{l}\text { (León-Sánchez } \\
\text { et al., 2005) }\end{array}$ & $\begin{array}{l}\text { 6-13 } \\
\text { Semi- } \\
\text { structured } \\
\text { interview }\end{array}$ & $\begin{array}{l}\text { Digestive system of the human body } \\
\text { They identify two digestive system models: } \\
\text { - The young ones only recognise the stomach. } \\
\text { - The old ones recognise other organs as well as the need to } \\
\text { distribute substances to different parts of the body. }\end{array}$ \\
\hline
\end{tabular}


Table 2. Categories related to the digestive system, which were identified in the children's drawings.

\begin{tabular}{|c|c|c|c|c|c|}
\hline \multicolumn{2}{|c|}{ CATEGORIES } & $\begin{array}{l}4 \text { years } \\
N=76\end{array}$ & $\begin{array}{c}5 \text { years } \\
\mathrm{N}=74\end{array}$ & $\begin{array}{c}6 \text { years } \\
\mathrm{N}=101\end{array}$ & $\begin{array}{c}7 \text { years } \\
\mathrm{N}=91\end{array}$ \\
\hline \multirow{2}{*}{$A_{D}$} & $A_{D 1}$ & $\begin{array}{c}8 \\
10.5 \%\end{array}$ & $\begin{array}{c}4 \\
5.4 \%\end{array}$ & - & - \\
\hline & $\mathrm{A}_{\mathrm{D} 2}$ & $\begin{array}{c}5 \\
6.6 \%\end{array}$ & $\begin{array}{c}3 \\
4.1 \%\end{array}$ & - & - \\
\hline \multirow[t]{2}{*}{$\mathrm{B}_{\mathrm{D}}$} & $\mathrm{B}_{\mathrm{D} 1}$ & $\begin{array}{c}36 \\
47.4 \%\end{array}$ & $\begin{array}{c}35 \\
47.3 \%\end{array}$ & $\begin{array}{c}38 \\
37.6 \%\end{array}$ & $\begin{array}{c}33 \\
36.3 \% \\
\end{array}$ \\
\hline & $\mathrm{B}_{\mathrm{D} 2}$ & $\begin{array}{c}27 \\
35.5 \% \\
\end{array}$ & $\begin{array}{r}32 \\
43.2 \% \\
\end{array}$ & $\begin{array}{c}58 \\
57.4 \% \\
\end{array}$ & $\begin{array}{c}43 \\
47.3 \% \\
\end{array}$ \\
\hline \multicolumn{2}{|c|}{$\mathrm{C}_{\mathrm{D}}$} & -- & -- & $\begin{array}{c}5 \\
5.0 \%\end{array}$ & $\begin{array}{c}15 \\
16.5 \%\end{array}$ \\
\hline
\end{tabular}


3

4

5

6

7

8

9

Table 3. Types of depictions of the digestive system, carried out by the children from five to seven years of age.

\begin{tabular}{|c|c|c|c|}
\hline \multicolumn{2}{|c|}{$\begin{array}{l}\text { TYPES OF DRAWINGS } \\
\qquad(5 \rightarrow 7 \text { years })\end{array}$} & $\begin{array}{l}\text { THE CHARACTERISTIC OF THE } \\
\text { CHANGE }\end{array}$ & $\begin{array}{c}\text { TOTAL } \\
\mathrm{n}=32\end{array}$ \\
\hline \multirow{4}{*}{ 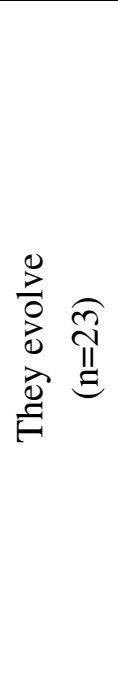 } & $\mathrm{A}_{\mathrm{D} 1} / \mathrm{A}_{\mathrm{D} 2} \rightarrow \mathrm{B}_{\mathrm{D} 2}$ & $\begin{array}{c}\text { No exits are identified } \\
\rightarrow \\
\text { Exits are identified }\end{array}$ & $\begin{array}{c}6 \\
18.8 \%\end{array}$ \\
\hline & $\mathrm{B}_{\mathrm{D} 1} \rightarrow \mathrm{B}_{\mathrm{D} 2}$ & $\begin{array}{l}\text { Two entries and two exits are identified } \\
\rightarrow \\
\text { One single entry and two exits are identified }\end{array}$ & $\begin{array}{c}10 \\
31.3 \%\end{array}$ \\
\hline & $\mathrm{B}_{\mathrm{D} 1} \rightarrow \mathrm{C}_{\mathrm{D}}$ & $\begin{array}{l}\text { Two entries and two exits are identified } \\
\rightarrow \\
\text { One entry and two exits are identified and it } \\
\text { includes the intestine }\end{array}$ & $\begin{array}{c}5^{(*)} \\
15.6 \%\end{array}$ \\
\hline & $\mathrm{B}_{\mathrm{D} 2} \rightarrow \mathrm{C}_{\mathrm{D}}$ & $\begin{array}{c}\text { One entry and two exits are identified } \\
\rightarrow \\
\text { It also includes the intestine }\end{array}$ & $\begin{array}{c}2 \\
6.3 \%\end{array}$ \\
\hline \multirow{2}{*}{ 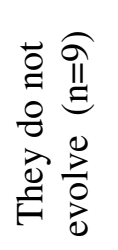 } & $\mathrm{B}_{\mathrm{D} 1} \rightarrow \mathrm{B}_{\mathrm{D} 1}$ & \multirow[b]{2}{*}{ No changes occur } & $\begin{array}{c}4 \\
12.5 \% \\
\end{array}$ \\
\hline & $\mathrm{B}_{\mathrm{D} 2} \rightarrow \mathrm{B}_{\mathrm{D} 2}$ & & $\begin{array}{c}5 \\
15.6 \%\end{array}$ \\
\hline
\end{tabular}

(*) Three children change their drawings twice. 
Table 4. General characteristics of the children's depictions with regard to the respiratory system.

\begin{tabular}{|c|c|c|c|c|c|c|}
\hline \multicolumn{2}{|c|}{ TYPE OF DEPICTION } & $\begin{array}{l}4 \text { years } \\
\mathrm{N}=76\end{array}$ & $\begin{array}{l}5 \text { years } \\
\mathrm{N}=74\end{array}$ & $\begin{array}{l}6 \text { years } \\
N=101\end{array}$ & $\begin{array}{l}7 \text { years } \\
\mathrm{N}=91\end{array}$ & $\begin{array}{c}\text { Total } \\
\mathrm{N}=342\end{array}$ \\
\hline \multicolumn{2}{|c|}{$\begin{array}{l}\text { With no internal organs in any of the } \\
\text { specimens. }\end{array}$} & $\begin{array}{c}52 \\
68.4 \%\end{array}$ & $\begin{array}{c}25 \\
33.8 \%\end{array}$ & $\begin{array}{c}23 \\
22.8 \%\end{array}$ & $\begin{array}{c}10 \\
11.0 \%\end{array}$ & $\begin{array}{c}110 \\
32.2 \%\end{array}$ \\
\hline \multirow{2}{*}{$\begin{array}{l}\text { With } \\
\text { internal } \\
\text { organs. }\end{array}$} & $\begin{array}{l}\text { The same in all of the } \\
\text { specimens. }\end{array}$ & $\begin{array}{c}24 \\
31.6 \%\end{array}$ & $\begin{array}{c}40 \\
54.1 \%\end{array}$ & $\begin{array}{c}60 \\
59.4 \%\end{array}$ & $\begin{array}{c}62 \\
68,1 \%\end{array}$ & $\begin{array}{c}186 \\
54.4 \%\end{array}$ \\
\hline & $\begin{array}{l}\text { The same in all of the } \\
\text { specimens except for the fish. }\end{array}$ & -- & $\begin{array}{c}9 \\
12.2 \% \\
\end{array}$ & $\begin{array}{c}18 \\
17.8 \% \\
\end{array}$ & $\begin{array}{c}19 \\
20.9 \% \\
\end{array}$ & $\begin{array}{c}46 \\
13.4 \% \\
\end{array}$ \\
\hline
\end{tabular}


Table 5. Categories related to the respiratory system identified in the drawings of the children

\begin{tabular}{|c|c|c|c|c|c|c|c|c|c|}
\hline \multirow{2}{*}{\multicolumn{2}{|c|}{ Categories }} & \multicolumn{2}{|c|}{4 years } & \multicolumn{2}{|c|}{5 years } & \multicolumn{2}{|c|}{6 years } & \multicolumn{2}{|c|}{7 years } \\
\hline & & $\begin{array}{c}\text { G. I } \\
n=76\end{array}$ & G. II & $\begin{array}{c}\text { G. I } \\
n=65\end{array}$ & $\begin{array}{c}\text { G. II } \\
\mathbf{n}=9\end{array}$ & $\begin{array}{c}\text { G. I } \\
\mathbf{n}=83\end{array}$ & $\begin{array}{l}\text { G. II } \\
n=18\end{array}$ & $\begin{array}{c}\text { G. I } \\
\mathrm{n}=72\end{array}$ & $\begin{array}{l}\text { G. II } \\
\mathrm{n}=19\end{array}$ \\
\hline \multirow[t]{2}{*}{$A_{R}$} & $\mathrm{~A}_{\mathrm{R} 1}$ & $\begin{array}{c}40 \\
52.6 \%\end{array}$ & -- & $\begin{array}{c}15 \\
23.1 \%\end{array}$ & -- & $\begin{array}{c}9 \\
10.8 \%\end{array}$ & -- & $\begin{array}{c}1 \\
1.4 \%\end{array}$ & -- \\
\hline & $\mathrm{A}_{\mathrm{R} 2}$ & $\begin{array}{c}12 \\
15.8 \% \\
\end{array}$ & -- & $\begin{array}{c}10 \\
15.4 \% \\
\end{array}$ & -- & $\begin{array}{c}14 \\
16.9 \% \\
\end{array}$ & -- & $\begin{array}{c}9 \\
12.5 \% \\
\end{array}$ & -- \\
\hline \multirow[t]{2}{*}{$\mathrm{B}_{\mathrm{R}}$} & $\mathrm{B}_{\mathrm{R} 1}$ & $\begin{array}{c}18 \\
23.7 \% \\
\end{array}$ & -- & $\begin{array}{c}23 \\
35.4 \% \\
\end{array}$ & -- & $\begin{array}{c}16 \\
19.3 \%\end{array}$ & -- & $\begin{array}{c}14 \\
19.4 \%\end{array}$ & -- \\
\hline & $\mathrm{B}_{\mathrm{R} 2}$ & $\begin{array}{c}4 \\
5.3 \% \\
\end{array}$ & -- & $\begin{array}{c}3 \\
4.6 \% \\
\end{array}$ & -- & $\begin{array}{c}3 \\
3.6 \% \\
\end{array}$ & -- & -- & -- \\
\hline \multirow{3}{*}{$\mathrm{C}_{\mathrm{R}}$} & $\mathrm{C}_{\mathrm{R} 1}$ & -- & -- & $\begin{array}{c}4 \\
6.2 \%\end{array}$ & -- & $\begin{array}{c}7 \\
8.4 \%\end{array}$ & $\begin{array}{c}3 \\
16.7 \%\end{array}$ & -- & $\begin{array}{c}2 \\
10.5 \%\end{array}$ \\
\hline & $\mathrm{C}_{\mathrm{R} 2}$ & -- & -- & $\begin{array}{c}3 \\
4.6 \%\end{array}$ & -- & $\begin{array}{c}11 \\
13.3 \%\end{array}$ & $\begin{array}{c}1 \\
5.6 \%\end{array}$ & $\begin{array}{c}14 \\
19.4 \%\end{array}$ & $\begin{array}{c}4 \\
21.1 \%\end{array}$ \\
\hline & $\mathrm{C}_{\mathrm{R} 3}$ & $\begin{array}{c}2 \\
2.6 \%\end{array}$ & -- & $\begin{array}{c}3 \\
4.6 \%\end{array}$ & -- & $\begin{array}{c}13 \\
15.7 \%\end{array}$ & $\begin{array}{c}6 \\
33.3 \%\end{array}$ & $\begin{array}{c}10 \\
13.9 \%\end{array}$ & $\begin{array}{c}7 \\
36.8 \%\end{array}$ \\
\hline \multicolumn{2}{|c|}{$D_{R}$} & -- & -- & $\begin{array}{c}4 \\
6.2 \%\end{array}$ & $\begin{array}{c}9 \\
100 \%\end{array}$ & $\begin{array}{c}10 \\
12.0 \%\end{array}$ & $\begin{array}{c}8 \\
44.4 \%\end{array}$ & $\begin{array}{c}24 \\
33.3 \% \\
\end{array}$ & $\begin{array}{c}6 \\
31.6 \% \\
\end{array}$ \\
\hline
\end{tabular}

G.I: Children who make the same depiction for all the specimens $(\mathrm{n}=296)$.

G.II: Children who make the same depiction for human/dog/duck. In the case of the fish, they only depict the gills (The $\mathrm{E}_{\mathrm{R}}$ category) $(\mathrm{n}=46)$. 
Table 6. Types of depictions of the respiratory system made by the children aged five to seven years of age

\begin{tabular}{|c|c|c|c|c|}
\hline \multirow{2}{*}{\multicolumn{2}{|c|}{$\begin{array}{l}\text { TYPES OF DRAWINGS } \\
\qquad(5 \rightarrow 7 \text { years })\end{array}$}} & \multirow{4}{*}{$\begin{array}{c}\text { CHARACTERISTIC OF THE } \\
\text { CHANGE } \\
\text { Does not identify any internal organs. } \\
\rightarrow \\
\text { Identifies the lungs and other organs. }\end{array}$} & \multicolumn{2}{|c|}{ TOTAL $(n=32)$} \\
\hline & & & \multirow{3}{*}{$\begin{array}{c}\begin{array}{c}\text { G. I } \\
\mathbf{n = 2 0}\end{array} \\
3^{*} \\
15.0 \%\end{array}$} & \multirow{3}{*}{$\begin{array}{r}\text { G. II } \\
\mathbf{n}=12 \\
--\end{array}$} \\
\hline \multirow{7}{*}{ 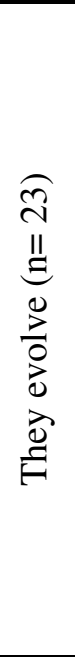 } & $\mathrm{A}_{\mathrm{R} 1} / \mathrm{A}_{\mathrm{R} 2} \rightarrow \mathrm{C}_{\mathrm{R} 2}$ & & & \\
\hline & $\mathrm{A}_{\mathrm{R} 2} \rightarrow \mathrm{C}_{\mathrm{R} 3}$ & & & \\
\hline & $\mathrm{B}_{\mathrm{R} 1} \rightarrow \mathrm{C}_{\mathrm{R} 1}$ & \multirow{3}{*}{$\begin{array}{l}\text { Identifies the stomach or the heart } \\
\text { Identifies the lungs as well. }\end{array}$} & \multirow{3}{*}{$\begin{array}{c}3 \\
15.0 \%\end{array}$} & \multirow{3}{*}{$\begin{array}{c}4 \\
33.3 \%\end{array}$} \\
\hline & $\mathrm{B}_{\mathrm{R} 1} / \mathrm{B}_{\mathrm{R} 2} \rightarrow \mathrm{C}_{\mathrm{R} 2}$ & & & \\
\hline & $\mathrm{B}_{\mathrm{R} 1} \rightarrow \mathrm{C}_{\mathrm{R} 3}$ & & & \\
\hline & $\mathrm{A}_{\mathrm{R} 1} / \mathrm{A}_{\mathrm{R} 2} \rightarrow \mathrm{D}_{\mathrm{R}}$ & $\begin{array}{c}\text { Does not identify any internal organs. } \\
\text { Only identifies the lungs }\end{array}$ & $\begin{array}{c}6 * * \\
30.0 \%\end{array}$ & $\begin{array}{c}3 \\
25.0 \%\end{array}$ \\
\hline & $\mathrm{B}_{\mathrm{R} 1} \rightarrow \mathrm{D}_{\mathrm{R}}$ & $\begin{array}{l}\text { Identifies the stomach } \\
\vec{\rightarrow} \\
\text { Only identifies the lungs }\end{array}$ & $\begin{array}{c}2 \\
10.0 \%\end{array}$ & $\begin{array}{c}2 \\
16 \% 7\end{array}$ \\
\hline \multirow{4}{*}{ 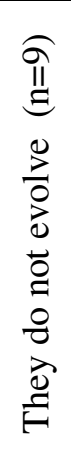 } & $\mathrm{B}_{\mathrm{R} 1} \rightarrow \mathrm{B}_{\mathrm{R} 1}$ & No changes occur & $\begin{array}{c}1 \\
5.0 \%\end{array}$ & -- \\
\hline & $\mathrm{B}_{\mathrm{R} 1} \rightarrow \mathrm{A}_{\mathrm{R} 2}$ & $\begin{array}{l}\text { Identifies the stomach } \\
\text { The air expands throughout the inside } \\
\text { of the body }\end{array}$ & $\begin{array}{c}2 \\
10.0 \%\end{array}$ & \\
\hline & $\mathrm{D}_{\mathrm{R}} \rightarrow \mathrm{C}_{\mathrm{R} 2}$ & Identifies the lungs & 3 & 3 \\
\hline & $\mathrm{D}_{\mathrm{R}} \rightarrow \mathrm{C}_{\mathrm{R} 3}$ & Identifies other organs too. & $15.0 \%$ & $25.0 \%$ \\
\hline
\end{tabular}

G. I: Children who make the same depiction for all the specimens.

G. II: Children who make the same depiction for human/Dog/Duck.

NB. The depiction changes in only happen once during the three-year period, except for the following cases: $(*)$ two subjects and $(* *)$ three subjects. 
Figure 1. Representative drawings of the digestive system for each category.

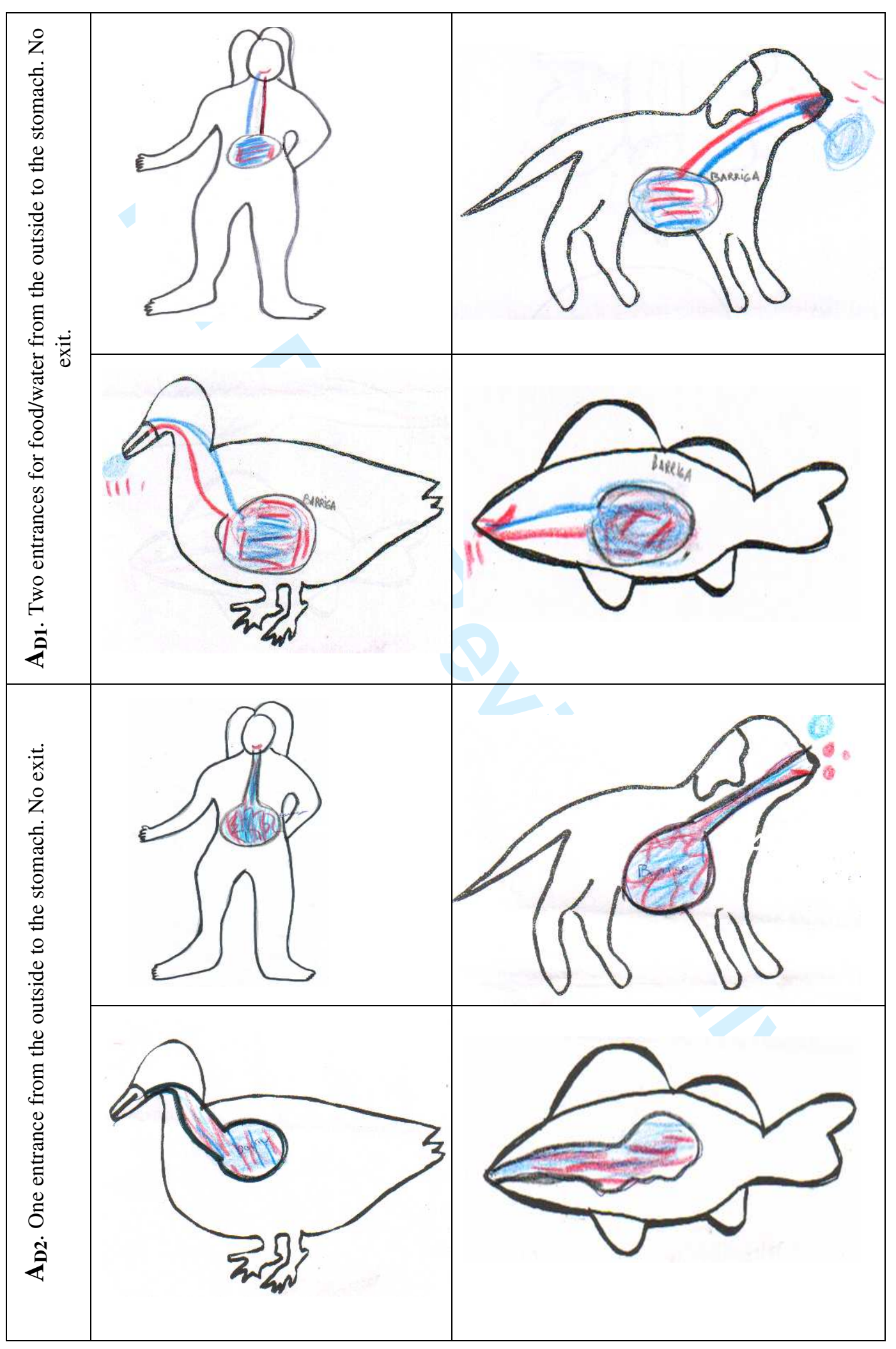




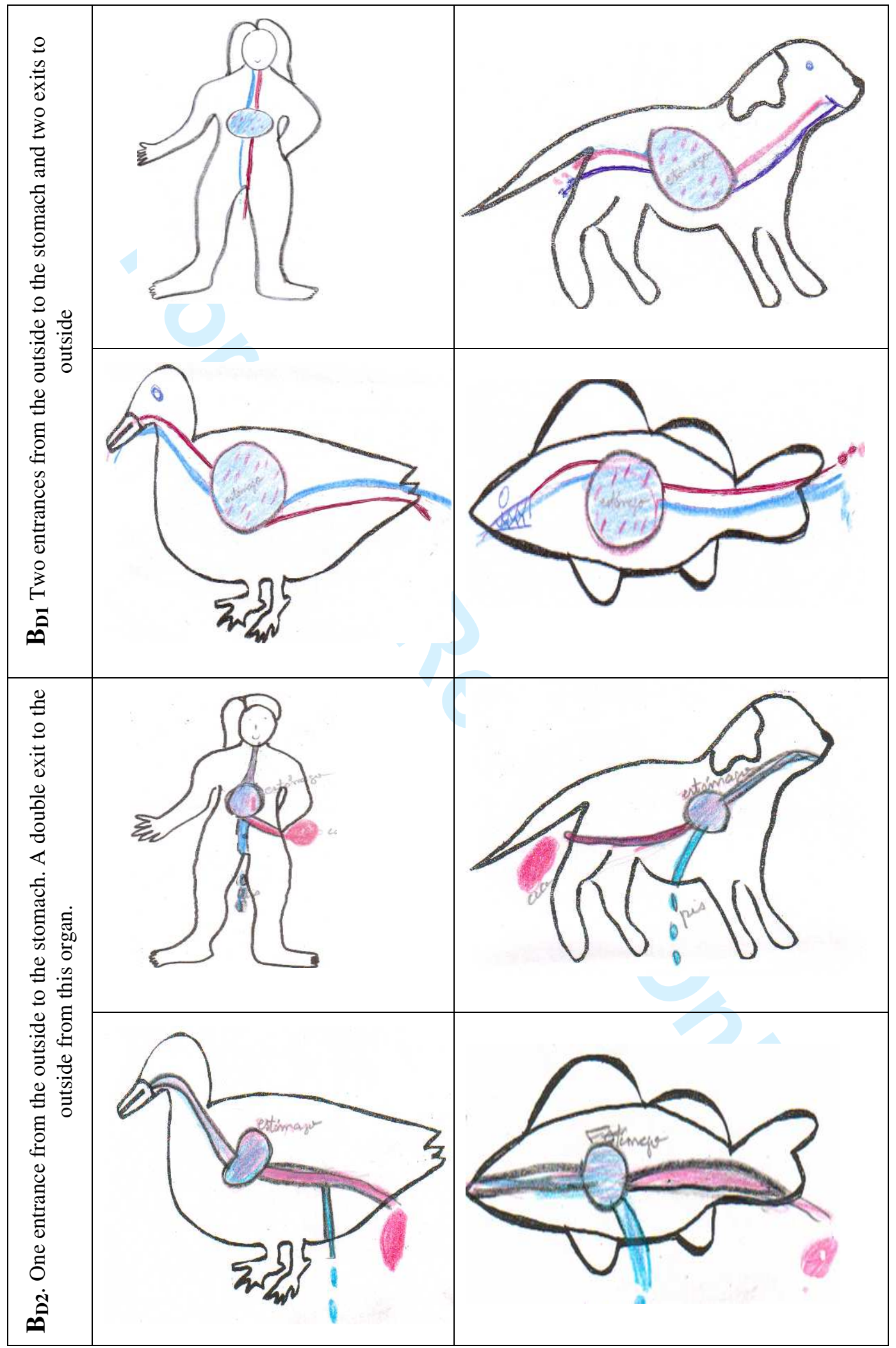




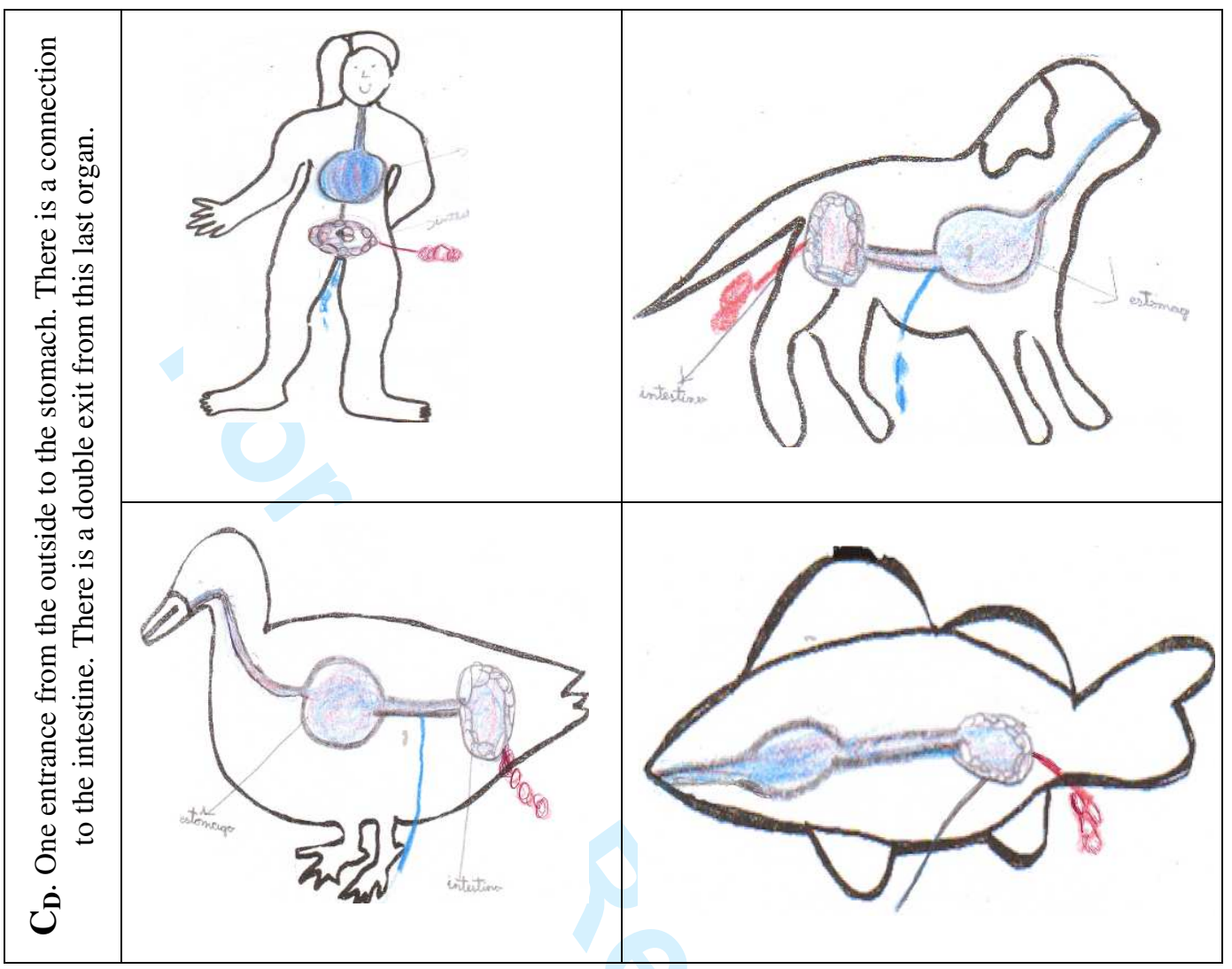


Figure 2. Representative drawings of the respiratory system for each category.

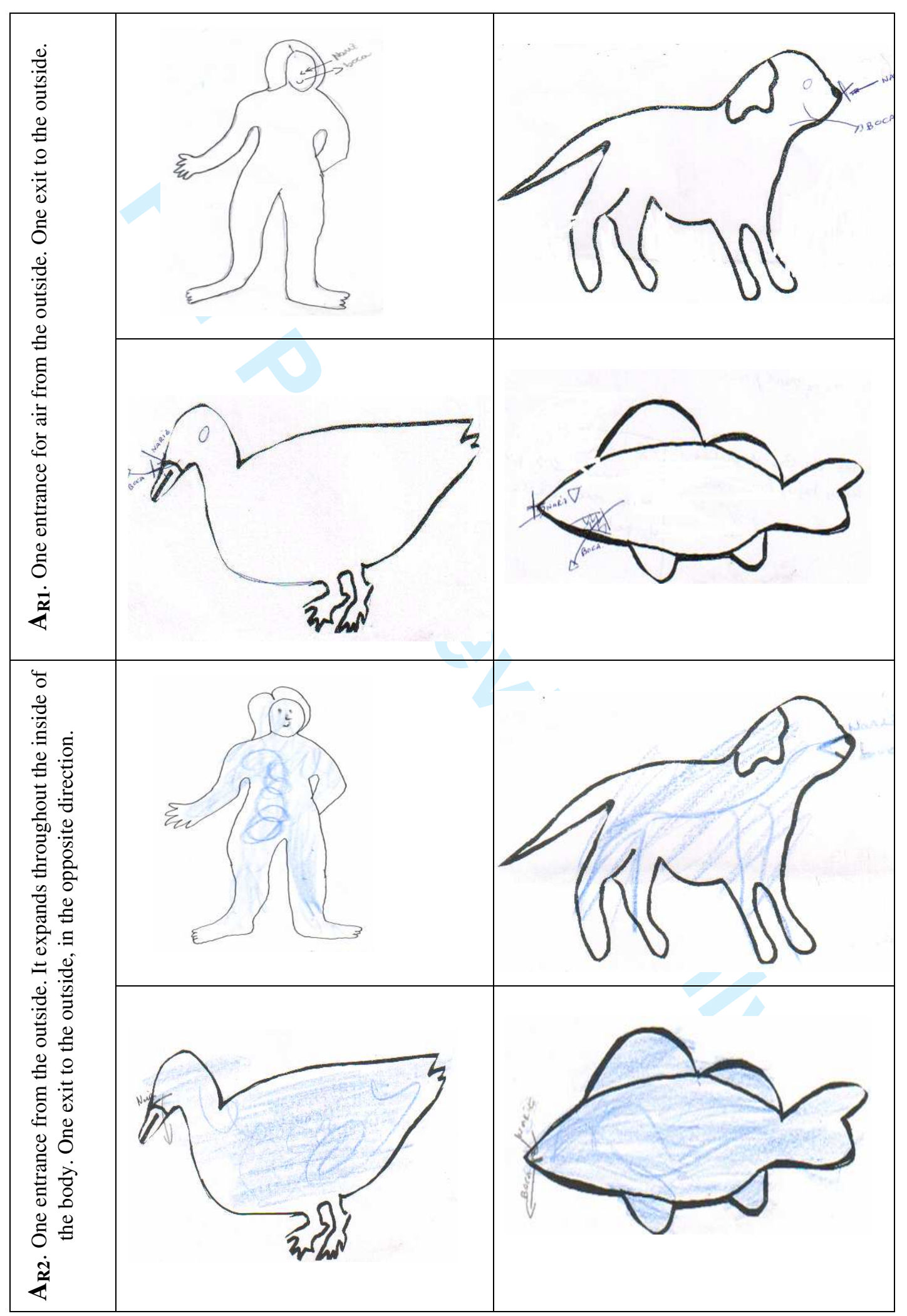




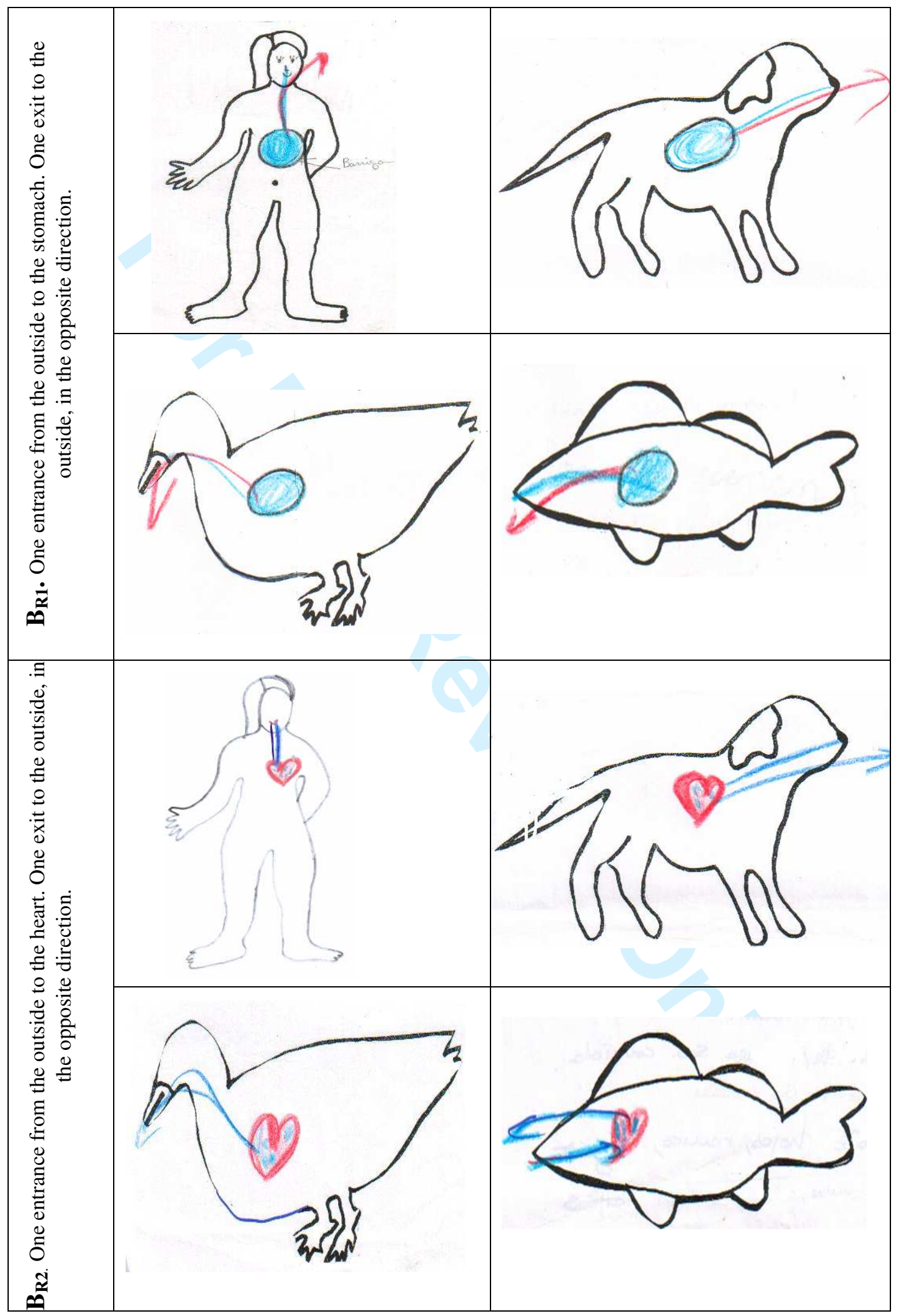




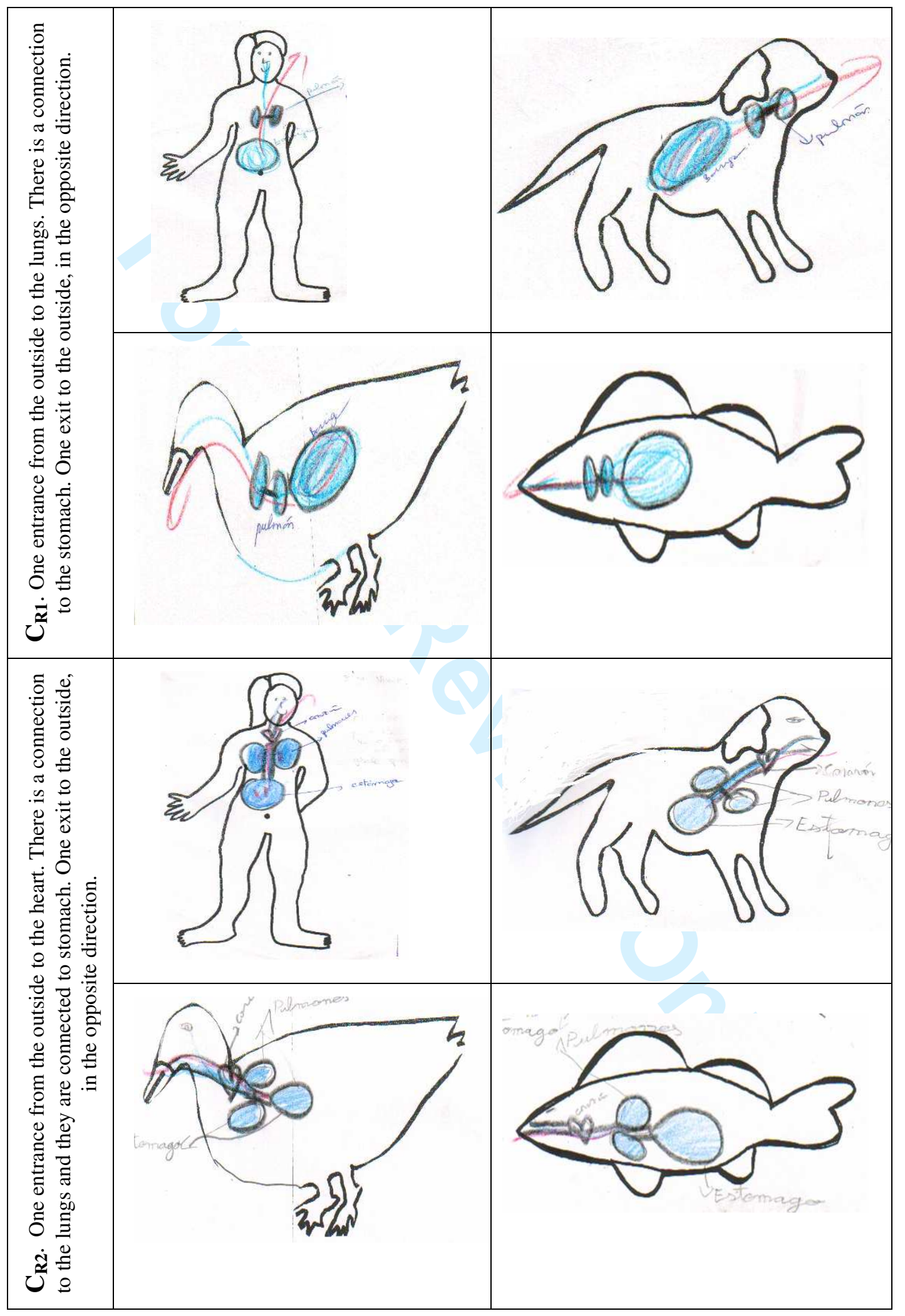




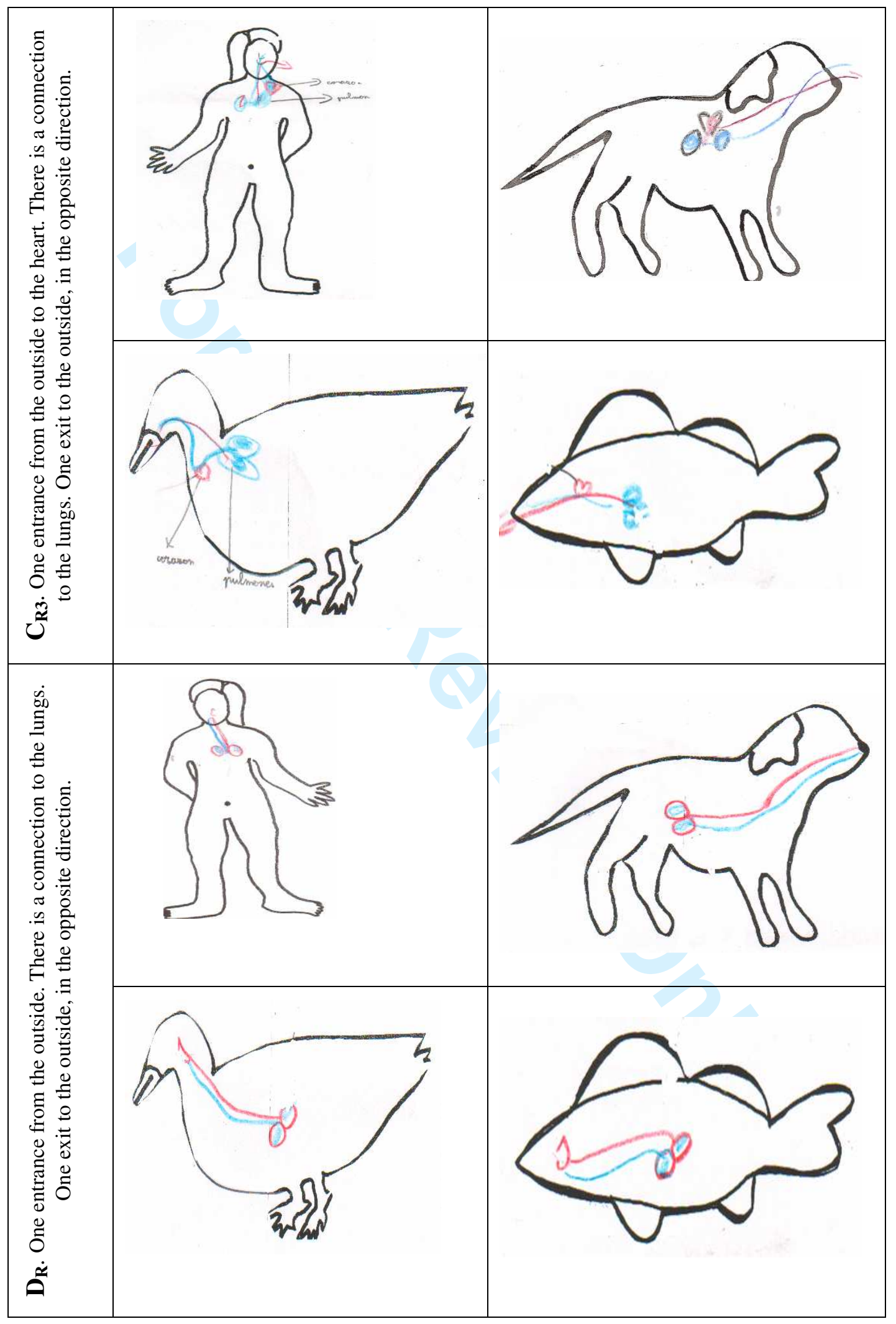


Figure 3. Representative drawing of the fish respiratory system $\left(\mathrm{E}_{\mathrm{R}}\right)$.

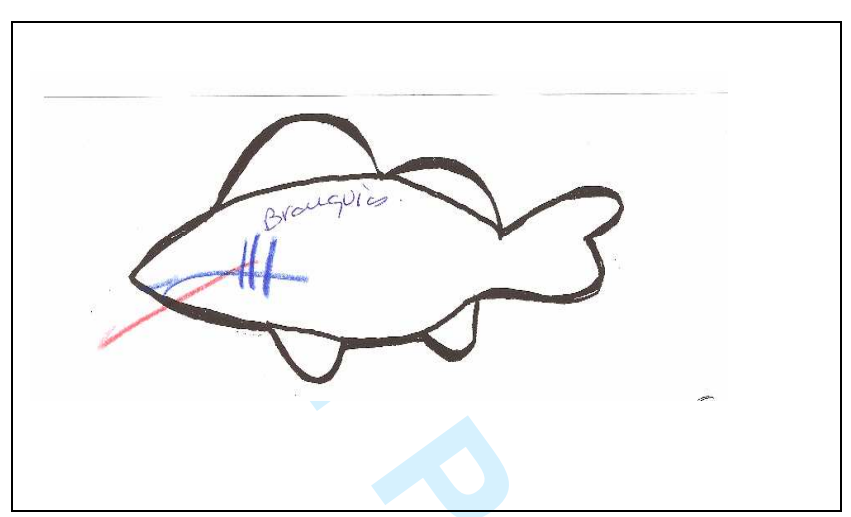

